\title{
An overview of the healthcare system in the Slovak Republic
}

\author{
Marko Kapalla • Dagmar Kapallová • Ladislav Turecký
}

Received: 3 November 2010 / Accepted: 23 November 2010/Published online: 8 December 2010

(C) European Association for Predictive, Preventive and Personalised Medicine 2010

\begin{abstract}
Healthcare system in Slovakia is neither Bismarck nor Beveridge nor National Health Insurance model, although it has certain features of all. The healthcare contributions are mandatory and are paid to the health insurance company. An insured citizen is almost unlimited as for the amount of healthcare spending but the reimbursement limits are set for the particular healthcare providers. Over $98 \%$ of the population is covered by health insurance. Public healthcare expenditure has been approximately 3400 millions $€$ in 2009 , which represents around $5.36 \%$ of gross domestic product. Around $78 \%$ of the 5.4 million population may be regarded to as relatively healthy. The $22 \%$ suffer of the most common diseases such as cardiovascular diseases, diabetes, respiratory diseases, psychiatric diseases, infectious diseases and cancer. New government has now a unique opportunity to implement the concept of predictive, preventive and personalized medicine for the benefit of each citizen and the entire country.
\end{abstract}

M. Kapalla is National Representative of EPMA in the Slovac Republic.

M. Kapalla • D. Kapallová

European Association for Predictive,

Preventive and Personalised Medicine (EPMA),

Avenue des Volontaire 19,

1160 Brussels, Belgium

M. Kapalla $(\square)$

Negentropic Systems,

Murgašova 12,

03401 Ružomberok, Slovakia

e-mail: kapalla@epmanet.eu

M. Kapalla

e-mail: marko.kapalla@gmail.com

L. Turecký

Institute of Medical Chemistry, Biochemistry and Clinical Biochemistry, Faculty of Medicine, Comenius University, Sasinkova 2

81108 Bratislava, Slovakia
Keywords Slovak Republic · Healthcare system · Prediction · Prevention · Personalized medicine . Recommendations

\section{Introduction}

This article is aimed at giving a brief overview of the healthcare system in the Slovak Republic and the state of the implementation of the predictive, preventive and personalized medicine in this system. All available data given here within can be compared to the data and information from healthcare systems of other countries, can help in finding the particular differences, as well as it can help anyone to be more familiar with the healthcare system in the Slovak Republic.

Slovak Republic was established in January 1993 after two federative republics of former Czechoslovakia decided to split into two independent states - the Czech Republic and the Slovak Republic. Therefore, the similarity of these healthcare systems may be expected.

Slovak Republic is located in the central Europe and neighbors with the Czech Republic, Poland, Austria, Hungary and Ukraine (Fig. 1). Slovakia is the member of the European Union and NATO since 2004. The number of inhabitants was over 5.4 million in March 2010. Basic data and description of the Slovak Republic is summarized in the Table 1 .

\section{Healthcare system in the Slovak Republic}

Healthcare system in the Slovak Republic (Figs. 2, 3) is neither Bismarck nor Beveridge nor National Health Insurance model, although it has certain features of all. There is virtually $100 \%$ solidarity implemented in the 


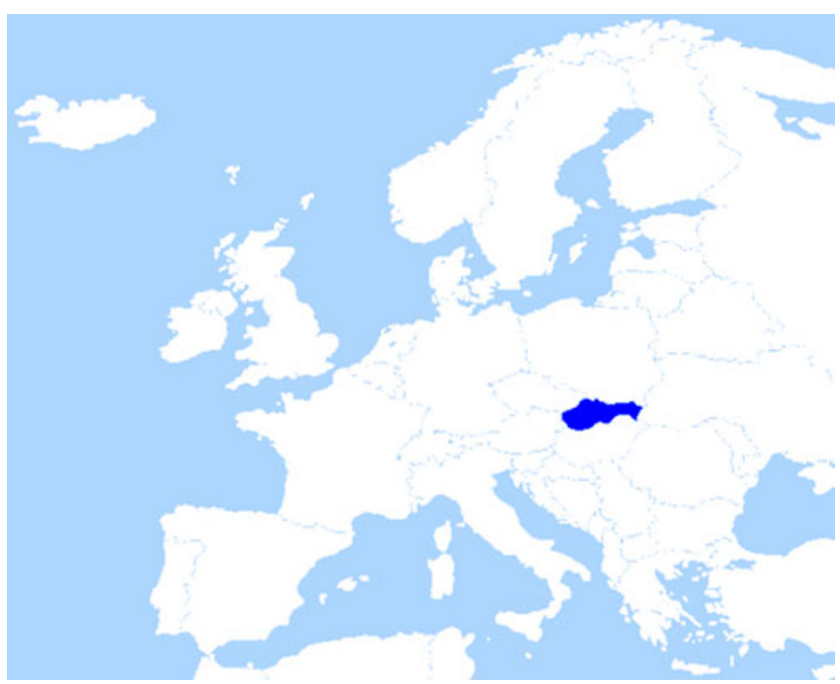

Fig. 1 Location of the Slovak Republic (Slovakia) in Europe. Neighboring countries: Czech Republic, Poland, Austria, Hungary and Ukraine

system-people who earn more pay more, those who earn less pay less, but all receive the same healthcare. Each employed citizen has to pay so-called "healthcare contributions" which in total represent $14 \%$ of the monthly income, of which $4 \%$ is paid by the employee and $10 \%$ is paid extra by the employer. Self-employed people have to pay $14 \%$ of their income themselves. Health insurance for the unemployed people, children, retired people, women on the maternity leave is paid by the state at a different (lower) rate, which is now $4.9 \%$ of an average monthly income in the Slovak Republic. The healthcare contributions are mandatory and are paid to the health insurance company (HIC) of the employee's choice. Currently there are three health insurance companies in the Slovak Republic, of which one is owned by the state, insuring $65 \%$ of the population, and the other two are private companies insuring together $33 \%$ of the population (Table 2). The current system of healthcare contributions is a subject to change in January 2011 if approved by the National Council of the Slovak Republic.

Taking into consideration that an average monthly wage is $725 €$, each employee pays $725 € \times 0.04$, this is $30 €$ and the employer pays for the employee additional $725 € \times 0.1$, this is $72.5 €$. Thus, in total, the health insurance company receives $102.5 €$ a month for the particular employee with an average wage. The maximum amount paid as the healthcare contribution is limited by the legislation to $315 €$. This means that an employee earning $2250 €$ a month, pays $2250 € \times 0.04$, this is $90 €$ and the employer pays additional $225 €$. The same amount is paid by an employee earning anything above $2250 €$. This amount of $2250 €$ is calculated as 3 -fold of an average salary in the Slovak Republic in the previous period of time.

On average, $52 €$ per citizen is paid by the health insurance company to the caregivers a month (Table 2). Regardless the amount paid, all citizens receive the same

Table 1 The basic data on Slovakia, GDP $=$ Gross Domestic Product, $\mathrm{mln}=$ million

\begin{tabular}{|c|c|c|}
\hline SLOVAKIA & Data & Source of the data \\
\hline \multirow[t]{2}{*}{ Inhabitants (March 2010) } & 5426000 & http://portal.statistics.sk/showdoc.do?docid $=5654$ \\
\hline & $\begin{array}{l}48.61 \% \text { males } \\
51.39 \% \text { females }\end{array}$ & http://portal.statistics.sk/showdoc.do?docid $=6768$ \\
\hline Area & $49034 \mathrm{~km}^{2}$ & http://www.vlada.gov.sk/7887/slovensko.php?menu=1265 \\
\hline Population density & $109 / \mathrm{km}^{2}$ & http://www.vlada.gov.sk/7887/slovensko.php?menu=1265 \\
\hline Cities & 138 & http://www.vlada.gov.sk/7887/slovensko.php?menu=1265 \\
\hline Capital & Bratislava & http://www.vlada.gov.sk/7887/slovensko.php?menu=1265 \\
\hline \multirow{2}{*}{$\begin{array}{l}\text { GDP at current prices } \\
\text { [EUR, 2009] and the } \\
\text { prognosis for } 2010\end{array}$} & $63331 \mathrm{mln}$ & http://portal.statistics.sk/showdoc.do?docid=17677 \\
\hline & $65914 \mathrm{mln}$ & $\begin{array}{l}\text { http://www.finance.gov.sk/Documents/ } \\
\text { Ifp/Ekonomicke_prognozy/Progn_sep2010/ } \\
\text { final_prognozy_web_SEP2010.pdf }\end{array}$ \\
\hline Currency & Euro, since January 1, 2009 & http://www.vlada.gov.sk/7887/slovensko.php?menu=1265 \\
\hline $\begin{array}{l}\text { EU and NATO } \\
\text { member since }\end{array}$ & 2004 & $\begin{array}{l}\text { http://europa.eu/about-eu/member-countries/index_en.htm } \\
\text { http://www.nato.int/cps/en/natolive/topics_52044.htm }\end{array}$ \\
\hline GDP per capita [EUR] & 12147 & estimates for $2010(65914 \mathrm{mln} / 5426000)$ \\
\hline $\begin{array}{l}\text { Total employment } \\
\left(2^{\text {nd }} Q 2010\right)\end{array}$ & 2144000 & http://portal.statistics.sk/showdoc.do?docid $=7556$ \\
\hline $\begin{array}{l}\text { Unemployment rate } \\
\text { (July 2010) }\end{array}$ & $12.3 \%(375608)$ & http://portal.statistics.sk/showdoc.do?docid=20900 \\
\hline $\begin{array}{l}\text { Average monthly } \\
\text { wage [EUR] }\end{array}$ & 725 & http://portal.statistics.sk/showdoc.do?docid=24142 \\
\hline
\end{tabular}




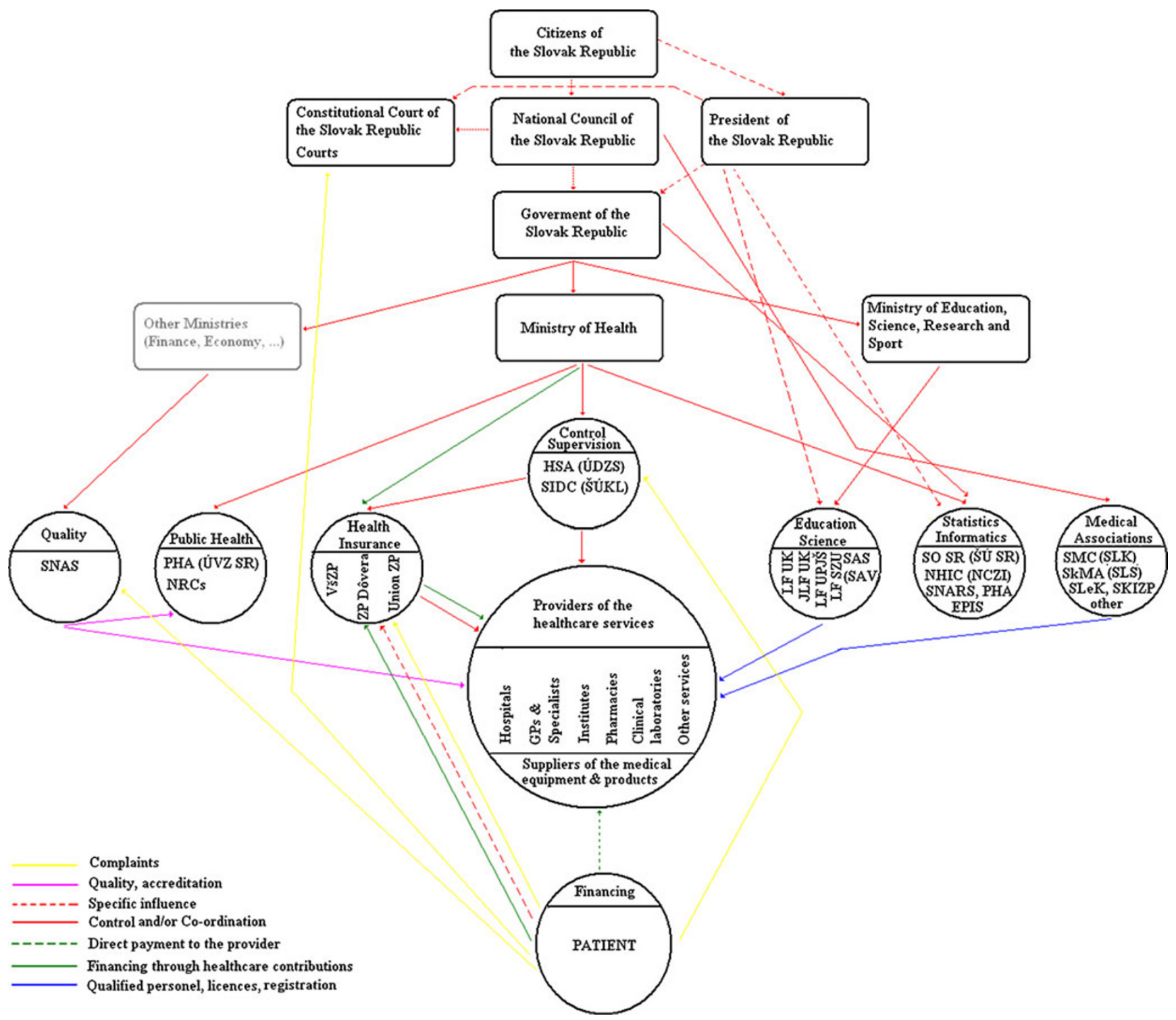

Fig. 2 Schematic description of the most important components of the healthcare system in the Slovak Republic (Abbreviations: HSA The Healthcare Surveillance Authority, SIDC-State Institute for Drug Control, SNAS - Slovak National Accreditation Service, PHA - Public Health Authority of the Slovak Republic, NRC - National Reference Center(s) for the particular diseases, ZP - Health Insurance Company, LF UK - Faculty of Medicine of the Comenius University, JLF UK Jessenius Faculty of Medicine of the Comenius University, LF UPJŠ Faculty of Medicine of P. J. Šafárik University, LF SZU - Faculty of

healthcare. The healthcare services which are not covered by the health insurance must be paid by the patient (i.e. many procedures in the dental care, plastic surgery and other procedures). There is a special legislation stating what is covered by the health insurance (Act No. 577/2004 Coll.) The structure of healthcare spending from the public money is outlined in Fig. 4

In brief, caregivers are paid pursuant to the Government regulation No. 776/2004 Coll. and No. 778/2004 Coll. as
Medicine of the Slovak Medical University, SAS - Slovak Academy of Sciences, SO SR - Statistical Office of the Slovak Republic, NHIC - National Health Information Center, SNARS - Slovak National Antimicrobial Resistance Surveillance System, EPIS Epidemiological Information System, SMC - Slovak Medical Chamber, SkMA - Slovak Medical Association, SLeK - Slovak Chamber of Pharmacists, SKIZP - Slovak Chamber of Other Healthcare Professionals). Color lines represent particular interactions between the components as stated in the legend

amended and supplemented by the later regulations. Each medical procedure is assigned an artificial value in 'points' and the real monetary value is assigned according to the law and according to the particular agreement of HIC with the caregiver in the case where the law leaves the space for the price negotiation. For example, if an enzymatic determination of total cholesterol in serum (code 3674a) is assigned 180 points and one point has the agreed value of $0.00697 €$ then the caregiver (i.e. clinical laboratory) is paid 
Fig. 3 Closer look at the particular interactions among the components of the healthcare system in the Slovak Republic. The numbers stated under the drawings indicate the numbers of the particular components

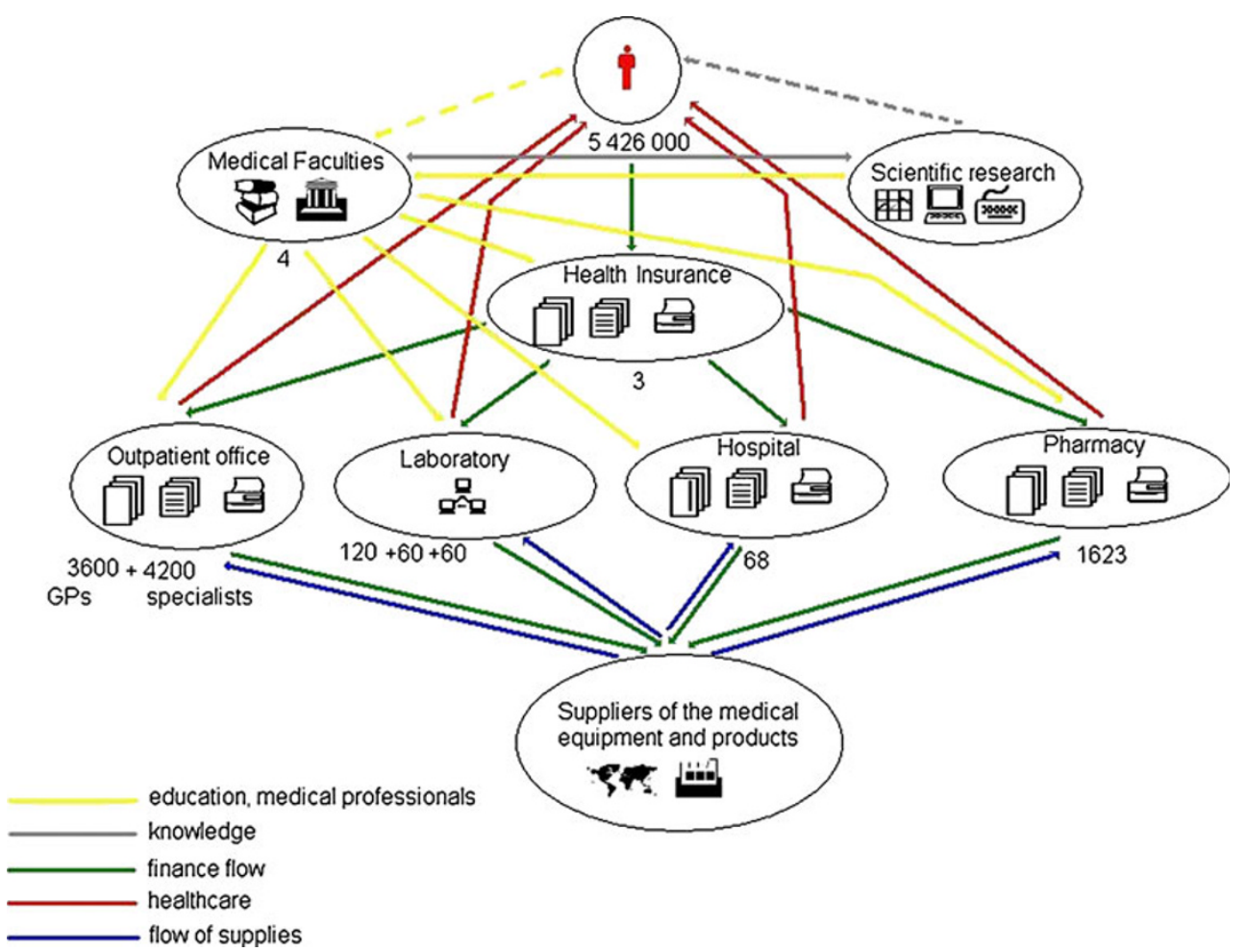

$180 \times 0.00697$, which makes $1.26 €$, for each determination of total cholesterol in the serum of a patient insured in the particular HIC. How the particular healthcare procedure was assigned a concrete value in points remains unclear for the majority of healthcare professionals, since there can hardly be found a link to the real world of economy. As a consequence, we find medical procedures which are severely undervalued and lead to financial losses and, on the other hand, there are some medical procedures that are extremely profitable for the caregiver. Another type of payment from HIC is so-called "capitation payment", applied in the case of the general practitioners, where a practitioner receives an amount of money per each patient registered in his office, regardless the patient visited, or did not visit, the office in the particular period of time HIC paid for. The situation is even more complicated by the so-called "reimbursement limits", representing the total amount of money paid by HIC for the services of the caregiver per a period of time. The reimbursement of the medical procedure that is done for the patient on top of this "limit" must be negotiated with $\mathrm{HIC}$, and frequently they are not reimbursed or reimbursed a year or more later.

The entire situation sometimes leads to the conflicts between the patient, health insurance companies, general practitioners, specialists, other caregivers and policy makers. The new catalog of the medical procedures is being prepared and it is expected to improve, hopefully, the current unsatisfactory situation.

\section{Selected healthcare-related legislation in the Slovak Republic}

The basic legislation related to the healthcare in the Slovak Republic is summarized as follows. The acts can be found in the electronic form at the web page of the Ministry of Justice of the Slovak Republic [1, 2] or at the commercial web site [3]:

- Act No 461/2003 Coll. of 30 October 2003 on social insurance;

- Act No 462/2003 Coll. of 30 October 2003 on compensation of earnings during an employee's temporary incapacity for work, and amending and supplementing certain acts;

- Gov. regulation. 212/2004 Coll. of 24 March 2004 Coll. on the competence of health professionals;

- Gov. regulation. 213/2004 Coll. of 24 March 2004 Coll. on continuing education of health professionals;

- Ordinance of Ministry of Health 366/2005 of 24 June $2005 \mathrm{Col}$. on the criteria and the evaluation of continuing education of health professionals;

- Act No 576/2004 Coll. of 22 September 2004 on healthcare, healthcare-related services and on the amendment and supplementing of certain acts;

- Act No 577/2004 Coll. of 21 October 2004 on the scope of healthcare covered by public health insurance and on the reimbursement of healthcare-related services, as amended by later regulations; 
Table 2 Basic data on healthcare system in the Slovak Republic as available from the reliable resources. There is no detailed source of the complex data of this kind, available electronically from the official health institutions. GDP $=$ Gross Domestic Product, mln $=$ million

\begin{tabular}{|c|c|c|}
\hline Item & Data & Source \\
\hline $\begin{array}{l}\text { Healthcare expenditure } \\
\text { (2009) [EUR] }\end{array}$ & $3400 \mathrm{mln}$ & $\begin{array}{l}\text { http://www.cenastatu.sme.sk/2009/Eur/ } \\
\text { http://www.nrsr.sk/Default.aspx?sid=zakony/ } \\
\text { cpt\&ZakZborID=13\&CisObdobia=5\&ID=18 }\end{array}$ \\
\hline $\begin{array}{l}\text { Healthcare expenditure as \% } \\
\text { of GDP }\end{array}$ & approx. $5.36 \%(3400 / 63331)$ & calculation by the authors \\
\hline $\begin{array}{l}\text { Health insurance expenditure } \\
\text { per capita in } 2009 \text { [EUR] }\end{array}$ & 612 & http://www.cenastatu.sme.sk/2009/Eur/ \\
\hline $\begin{array}{l}\text { Drugs consumption } \\
\text { (2009) [EUR] }\end{array}$ & $\begin{array}{l}1125 \mathrm{mln} 33 \% \\
\text { of healthcare } \\
\text { expenditure }\end{array}$ & $\begin{array}{l}\text { http://www.cenastatu.sme.sk/2009/Eur/, } \\
\text { annual reports of HICs, http://portal. } \\
\text { statistics.sk/showdoc.do?docid=20468 }\end{array}$ \\
\hline $\begin{array}{l}\text { Hospital healthcare } \\
\text { (2009) [EUR] }\end{array}$ & $1008 \mathrm{mln}$ & http://www.cenastatu.sme.sk/2009/Eur/ \\
\hline $\begin{array}{l}\text { Outpatient healthcare } \\
\text { (2009) [EUR] }\end{array}$ & $518 \mathrm{mln}$ & http://www.cenastatu.sme.sk/2009/Eur/ \\
\hline $\begin{array}{l}\text { Diagnostics (clinical } \\
\text { laboratories, X-ray, etc.) } \\
\text { (2009) [EUR] }\end{array}$ & $329 \mathrm{mln}$ & http://www.cenastatu.sme.sk/2009/Eur/ \\
\hline Medical aids (2009) [EUR] & $124 \mathrm{mln}$ & http://www.cenastatu.sme.sk/2009/Eur/ \\
\hline $\begin{array}{l}\text { Medical Emergecy } \\
\text { services (2009) }\end{array}$ & $70 \mathrm{mln}$ & http://www.cenastatu.sme.sk/2009/Eur/ \\
\hline Physicians & 21000 & $\begin{array}{l}\text { http://www.lekom.sk - central register } \\
\text { of medical doctors }\end{array}$ \\
\hline Outpatient Offices - GPs & approx. 3600 & $\begin{array}{l}\text { http://www.udzs.sk/buxus/ } \\
\text { generate_page.php?page_id=237 }\end{array}$ \\
\hline Outpatient offices-specialists & approx. 4200 & estimate by the authors \\
\hline $\begin{array}{l}\text { Healthcare providers- } \\
\text { unique identifiers }\end{array}$ & 13501 & $\begin{array}{l}\text { http://www.udzs.sk/buxus/ } \\
\text { generate_page.php?page_id=237 }\end{array}$ \\
\hline Hospitals (July 31, 2010) & 68 & $\begin{array}{l}\text { http://www.udzs.sk/buxus/ } \\
\text { generate_page.php?page_id=237 }\end{array}$ \\
\hline Beds & 46742 & $\begin{array}{l}\text { http://portal.statistics.sk/ } \\
\text { showdoc.do?docid=20473 }\end{array}$ \\
\hline $\begin{array}{l}\text { Clinical Biochemistry and } \\
\text { Hematology Laboratories }\end{array}$ & $120+/-15$ & $\begin{array}{l}\text { qualified estimate by the authors, } \\
\text { no comprehensive list of all medical } \\
\text { laboratories is officially available }\end{array}$ \\
\hline $\begin{array}{l}\text { Clinical Microbiology } \\
\text { Laboratories }\end{array}$ & 60 & $\begin{array}{l}\text { Adresár mikrobiologických pracovísk, } \\
\text { Správy klinickej mikrobiológie, } \\
\text { 2, 2008, 14-50, ISSN 1335-8219 }\end{array}$ \\
\hline $\begin{array}{l}\text { Laboratories of Histopathology } \\
\text { and Cytology }\end{array}$ & 60 & $\begin{array}{l}\text { qualified estimate by the authors, no } \\
\text { comprehensive list of all medical } \\
\text { laboratories is officially available }\end{array}$ \\
\hline Pharmacies & 1623 & http://www.ezdravotnictvo.sk/?lekarne \\
\hline $\begin{array}{l}\text { Disability to work } \\
\text { (daily average, 2009) }\end{array}$ & 83515 & $\begin{array}{l}\text { http://portal.statistics.sk/ } \\
\text { showdoc.do?docid=15015 }\end{array}$ \\
\hline Faculties of Medicine & 4 & $\begin{array}{l}\text { www.fmed.uniba.sk, } \\
\text { http://www.jfmed.uniba.sk/, } \\
\text { http://www.upjs.sk/lekarska-fakulta/, } \\
\text { http://www.szu.sk/index.php?id=64 }\end{array}$ \\
\hline Health insurance companies & 3 & \\
\hline -state $(65 \%)$ & 3500000 insurees & http://www.vszp.sk/showdoc.do?docid=750 \\
\hline -private $(26 \%)$ & 1400000 insurees & http://www.dovera.sk/sk/o-nas/profil \\
\hline -private $(7 \%)$ & 367000 insurees & http://www.unionzp.sk/vyrocne-spravy.html \\
\hline $\begin{array}{l}\text { Infant mortality } \\
\text { (under } 1 \text { year of age) }\end{array}$ & 5.7 per 1000 life births & $\begin{array}{l}\text { http://portal.statistics.sk/files/Sekcie/ } \\
\text { sek_600/Demografia/ } \\
\text { Obyvatelstvo/2010/preddef_tab_09_aj.pdf }\end{array}$ \\
\hline $\begin{array}{l}\text { Neonatal mortality } \\
\text { (under } 28 \text { day of age) }\end{array}$ & 3.1 per 1000 life births & $\begin{array}{l}\text { http://portal.statistics.sk/files/Sekcie/sek_600/ } \\
\text { Demografia/Obyvatelstvo/2010/ } \\
\text { preddef_tab_09_aj.pdf }\end{array}$ \\
\hline Life expectancy at birth [years] & males $71.3 /$ females 78.7 & $\begin{array}{l}\text { http://portal.statistics.sk/files/Sekcie/sek_600/ } \\
\text { Demografia/Obyvatelstvo/2010/ } \\
\text { preddef_tab_09_aj.pdf }\end{array}$ \\
\hline
\end{tabular}


Table 2 (continued)

\begin{tabular}{|c|c|c|}
\hline Item & Data & Source \\
\hline Net reproduction rate (2009) & 0.676 & $\begin{array}{l}\text { http://portal.statistics.sk/files/Sekcie/sek_600/ } \\
\text { Demografia/Obyvatelstvo/2010/ } \\
\text { preddef_tab_09_aj.pdf }\end{array}$ \\
\hline Total fertility rate (2008) & 1.3 & $\begin{array}{l}\text { http://www.rokovania.sk/Rokovanie.aspx/ } \\
\text { BodRokovaniaDetail?idMaterial=8893 }\end{array}$ \\
\hline Deaths (2009) & $\begin{array}{l}52913 \\
27446 \text { males } \\
25467 \text { females }\end{array}$ & $\begin{array}{l}\text { http://portal.statistics.sk/files/Sekcie/sek_600/ } \\
\text { Demografia/Obyvatelstvo/2010/ } \\
\text { preddef_tab_09_aj.pdf }\end{array}$ \\
\hline Live births (2009) & 61217 & $\begin{array}{l}\text { http://portal.statistics.sk/files/Sekcie/sek_600/ } \\
\text { Demografia/Obyvatelstvo/2010/ } \\
\text { preddef_tab_09_aj.pdf }\end{array}$ \\
\hline $\begin{array}{l}\text { Average monthly wage in } \\
\text { healthcare [EUR] } \\
\text { (1st quarter 2010) }\end{array}$ & 642 & $\begin{array}{l}\text { http://portal.statistics.sk/ } \\
\text { showdoc.do?docid=24142 } \\
\text { Other data on salaries in healthcare in the } \\
\text { Slovak Republic are available at } \\
\text { http://www.naseplaty.sk on the basis of } \\
\text { web-based surveys of voluntary participants }\end{array}$ \\
\hline $\begin{array}{l}\text { Average monthly costs } \\
\text { of the health insurance } \\
\text { for the employee }+ \\
\text { employer [EUR] }\end{array}$ & $30+72.5=102.5$ & $\begin{array}{l}\text { calculated by the authors according to the } \\
\text { data on the average montly wage ( } 725) \\
\text { and the respective regulation }\end{array}$ \\
\hline $\begin{array}{l}\text { Maximum monthly costs } \\
\text { of the health insurance } \\
\text { for the employee }+ \\
\text { employer [EUR] }\end{array}$ & $90+225=315$ & $\begin{array}{l}\text { calculated by the authors according to the } \\
\text { data on the average monthly wage ( } 725) \\
\text { and the respective regulation }\end{array}$ \\
\hline
\end{tabular}

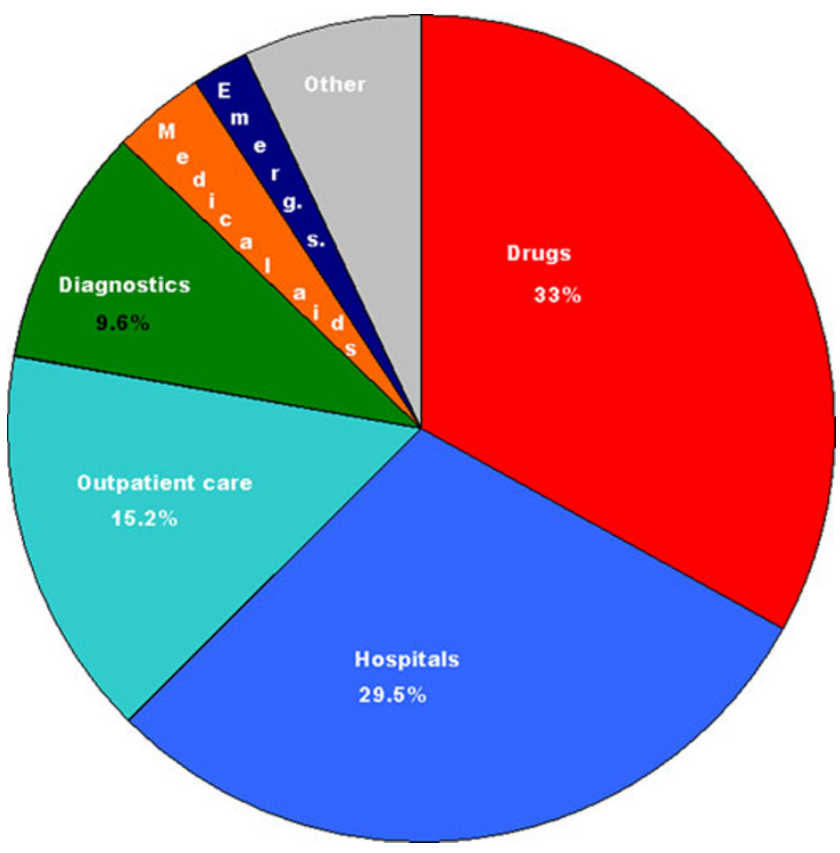

Fig. 4 Estimates of the major healthcare spending as a fraction of healthcare spending from the public resources (approx. $3400 \mathrm{mln}$. $€$ ) according to the annual reports of the health insurance companies in 2009. See also Table 2 for the absolute numbers and the source of the data. From the PPPM point of view it would bring more benefit for the citizens in the Slovak Republic if the consumption of drugs is decreased through engaging the emerging predictive power of clinical laboratory diagnostics and the power of the in vivo diagnostics and consequent preventive actions based on the complex results from these components of the healthcare system
- Act No 578/2004 Coll. of 21 October 2004 on healthcare providers, health workers and professional organizations in the health service, and amending and supplementing certain acts, as amended by later regulations;

- Act No 579/2004 Coll. of 21 October 2004 on the emergency medical service and amending and supplementing certain acts;

- Act No 580/2004 Coll. of 21 October 2004 on health insurance and amending and supplementing Act No 95/ 2002 Coll. on the insurance industry and amending and supplementing certain acts as amended;

- Act No 581/2004 of 21 October 2004 on health insurance companies and healthcare supervision, and amending and supplementing certain acts as amended;

- Gov. regulation No 776/2004 Coll. of 15 December 2004 issuing the catalogue of medical procedures;

- Gov. regulation No 778/2004 Coll. of 15 December 2004 on the amount of payment for healthcare reimbursed by health insurance company to the provider of the first aid medical service.

All acts mentioned above are meant as amended and supplemented by later regulations. According to the declaration of the new government of the Slovak Republic (since July 9, 2010) many of the acts mentioned above will be the subject to change in the next year. 


\section{Health of the population in the Slovak Republic}

The report on the public health status is submitted to the Government of the Slovak Republic every 2 years. The health status of the population in the Slovak Republic is extensively reviewed in the Report on the health of the population of the Slovak Republic in the period 2006-2008, submitted by the Ministry of Health and adopted by the government of the Slovak Republic in the Government resolution No 596/2009 Coll. [4, 5]. Unfortunately, there is no central, web-based electronic source of the complex information on the population health at present time. The most frequent source of the data on the public health still remains the scientific literature published in the Slovak Republic, congress presentations, research articles, web portals and the official reports by healthcare authorities. Certain statistics related to the health of the population are available at the web page of The Statistical Office of the Slovak Republic, The National Health Information Center, and The Public Health Authority of the Slovak Republic. The e-health project, coordinated by the National Health Information Center, however, is expected to offer such an information service when fully effective $[6,7]$.

Data related to the public health and the mortality in 2009 is summarized in the Figs. 5 and 6, respectively. It is rather difficult to assemble complex and up-to-date data on morbidity in the Slovak Republic. Nevertheless, certain information can be given on the basis of the report mentioned $[4,5,8]$. Similarly to the other countries, among the most frequent diseases in the Slovak Republic are cardiovascular diseases and diabetes, followed by chronic obstructive pulmonary disease, bronchial asthma, psychiatric diseases, injuries, infectious diseases and cancer. The influenza represents a special category in this statistics, since over 1.8 million cases of influenza have been reported in 2008. If, however, the influenza is taken as a minor temporal health complication, not taking into account individual cases of serious complications caused by influenza, then from the overall morbidity point of view we can objectively say that approximately $78 \%$ of the population of the Slovak Republic is relatively healthy. Although, this calculation is somehow dimmed by the possible co-morbidity of the influenza and other diseases, which is not statistically assessed here. Nonetheless, this number, related to the year 2008, is in a very good agreement with the previous data published in July, 2005, in the National Health Promotion Program, suggesting that around 78\% of men and $72 \%$ of women regarded their health status, subjectively, as "good" [9]. In the last year, 2009, the most frequent cause of death (Table 3, Fig. 6) were the diseases of the circulatory system, neoplasms, disease of the respiratory system, disease of the digestive system and other causes. External causes such as injury, accidents, poisoning, homicides and suicides represent $5.6 \%$ of all causes, thus $94.4 \%$ of deaths in the Slovak Republic can be attributed to only a few diseases mentioned above, which means that there is tremendous amount of the work to be done in order to improve the health of the people at higher age, with a special focuse on the mentioned diseases.

As reported, the most frequent diagnosis in the case of circulatory diseases is hypertension (30.4\%), ischemic heart
Fig. 5 Estimates of the morbidity in the Slovak Republic according to the data on the health status in the period 2006-2008. If the influenza is taken as a minor temporal health complication, then from the overall morbidity point of view, we can objectively say that approximately $78 \%(4.212$ million) of the 5.4 million population of the Slovak Republic is relatively healthy and $22 \%$ (1.188 million) suffer of the most frequent diseases displayed in the graph

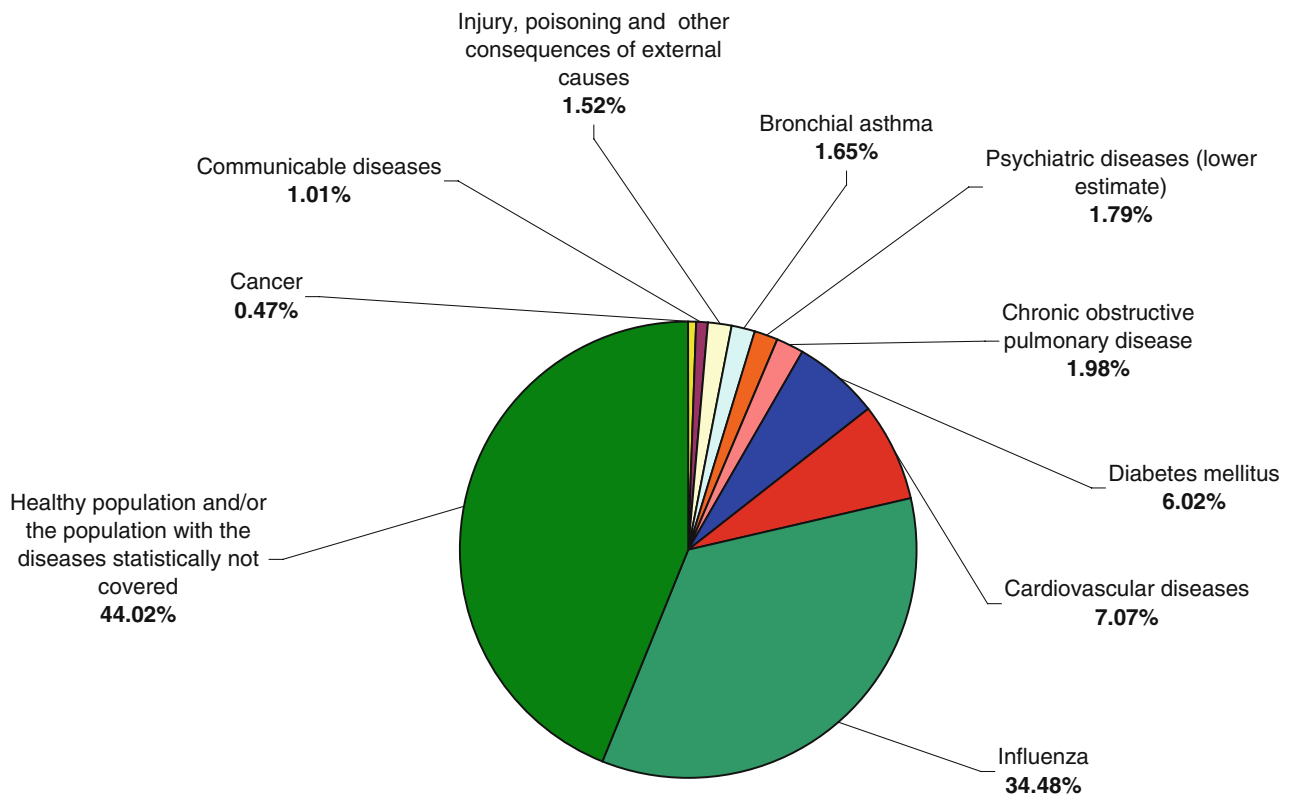




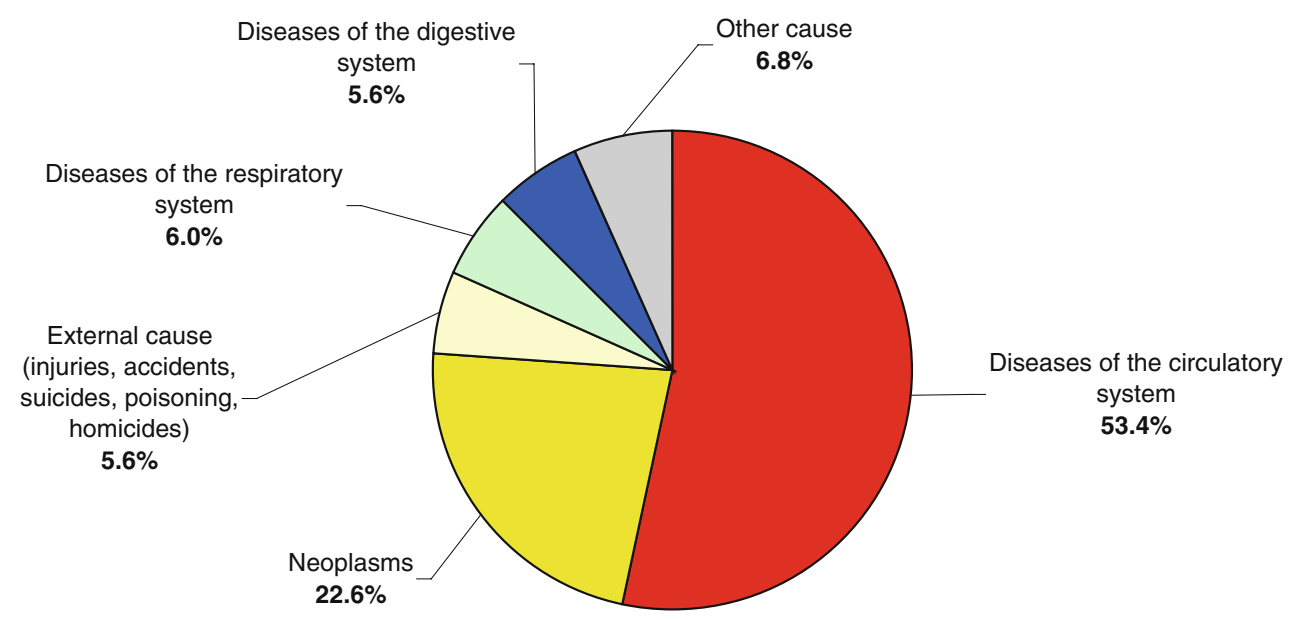

Fig. 6 Mortality in the Slovak Republic according to the data of the Statistical Office of the Slovak Republic [8]. Of the total amount of deaths (52913) reported in the year 2009, over half of the amount were caused by the diseases of the circulatory system (28265) and

disease $(24.3 \%)$, heart rhythm disorders $(19.5 \%)$, chronic heart failure $(5.7 \%)$, cardiomyopathy $(2.2 \%)$ and others $(17.9 \%)$. The most frequent malignant tumors in men are malignant neoplasms of skin (15.4\%), malignant neoplasms of bronchus and lung (14.6\%), malignant neoplasms of prostate $(9.5 \%)$, malignant neoplasm of colon $(8.2 \%)$, malignant neoplasm of rectum (5.1\%), malignant neoplasms of stomach (4.8\%). In women, the most frequent malignant tumors are malignant neoplasms of breast $(17.7 \%)$, other malignant neoplasms of skin (16.5\%), malignant neoplasms of colon (7\%), malignant neoplasms of corpus uteri $(6.6 \%)$, malignant neoplasms of cervix uteri $(5 \%)$, malignant neoplasms of bronchus and lung (3.7\%), malignant neoplasms of stomach (3.4\%). Diabetes mellitus type I was diagnosed in $8 \%$ and the diabetes mellitus type II in $89.75 \%$ of the diabetic patients $[4,5,9]$.

\section{Current information pool on PPPM in the Slovak Republic available in Slovak language}

From the point of view of predictive, preventive and personalized medicine (PPPM) it is important to monitor the progress of this novel concept in each country in order to transform the new ideas into the daily routine of the healthcare system. One possible way of monitoring the progress is the
11966 deaths were caused by cancer. In total, $94.4 \%$ of the deaths were caused by the disease and $5.6 \%$ of deaths were resulted from the external causes such as injury, accidents, poisoning, homicides, suicides

monitoring of the electronic information available in the native language. The current information about predictive, preventive and personalized medicine available in Slovak language is summarized in Table 4. As seen from this simple search, the most frequent aspect of PPPM in the Slovak language is related to prevention, and the information on the medical prediction can most frequently be found under the phrase "skríning" (screening) and "prognostický marker" (prognostic marker) rather than the phrase "prediction". At this point, it is important to note that the relevant information in the Czech language is easily comprehensive for the Slovak population and for this reason the majority of the web services usually don't have their Slovak equivalent if such a service is offered in the Czech language.

Although the number of hits per searched item may vary significantly over time, it is expected that in the longer period of time the number of hits will increase as the particular topic is increasingly discussed, published and implemented in the Slovak Republic

\section{Current programs for prediction in the Slovak Republic}

We understand the prediction as foreseeing a medical complication in an apparently healthy person on the basis of the evidence of relevant medical procedures and

Table 3 Mortality in the Slovak Republic in the year 2009 by gender, according to the data from the Statistical Office of the Slovak Republic [8]

\begin{tabular}{|c|c|c|c|c|c|c|c|}
\hline $\begin{array}{l}\text { Mortality } \\
2009\end{array}$ & $\begin{array}{l}\text { Disease of the } \\
\text { circulatory system }\end{array}$ & Neoplasms & $\begin{array}{l}\text { External } \\
\text { cause }\end{array}$ & $\begin{array}{l}\text { Disease of the } \\
\text { respiratory system }\end{array}$ & $\begin{array}{l}\text { Disease of the } \\
\text { digestive system }\end{array}$ & Other cause & Total \\
\hline Males & $12845(46.8 \%)$ & $6782(24.7 \%)$ & $2325(8.5 \%)$ & $1846(6.7 \%)$ & $1793(6.5 \%)$ & $1855(6.8 \%)$ & 27446 \\
\hline Females & $15420(60.6 \%)$ & $5184(20.4 \%)$ & $632(2.5 \%)$ & $1333(5.2 \%)$ & $1158(4.6 \%)$ & $1740(6.8 \%)$ & 25467 \\
\hline
\end{tabular}


Table 4 Electronic information available on the web in Slovak language via Google search on October 29, 2010. It is expected that in the longer period of time the number of hits will increase as the particular topics related to prediction, prevention and personalized medicine become more frequently discussed in Slovakia
"Searched phrase" in Slovak/English and (English equivalent)

Number of hits in www.google.com on October 29, 2010

Number of domains "sk"

67200000

"Zdravie" (health) at "sk"

1860000

"Zdravie" (health)

6590000

"Disease prediction"

78200

"Prediction of the disease"

823000

16000

3210

"Predictive, preventive and personalised medicine"

"Predikcia chorôb" (illness prediction)

0

"Predikcia ochorení" (disease prediction)

"Predpoved' ochorenia" (disease forecast)

"Predvídanie ochorenia" (disease forseeing)

"Predvídanie choroby" (illness forseeing)

"Prediktívne markery" (predictive markers)

1

"Prognostický marker" (prognostic marker)

"Marker prognózy ochorenia" (disease prognosis marker)

"Prognostický faktor ochorenia" (disease prognosis factor)

"Skríning" (screening) with the word "zdravie"

(health) (at "sk")

"Prevencia chorôb" (disease prevention)

"Prevencia ochorení" (illness prevention)

"Prevencia výskytu ochorení" (prevention of diseases)

"Primárna prevencia" (primary prevention)

"Zdravotné preventívne programy"

(preventive health programs)

"Personalizovaný prístup k pacientovi"

(personalized attitude towards patient)

"Personalizovaná medicína" at "sk" (personalized medicine)

"Personalizovaná liečba" (personalized treatment)

without the word "rakovina" (cancer)

"Personalizovaná terapia" (personalized therapy)

without the word "rakovina" (cancer)

\section{0}


Particular effort is being exerted by medical professionals in the case of applying cytostatic drugs only to the patients who will respond to the particular drug. The prediction on response is made on the basis of the genetic tests.

Monitoring of the quality of the tap water, water reservoirs, concentration of the pollens in the air, nutrition and the food safety is among the tasks of the Public Health Authority of the Slovak Republic [11], thus helping in the prediction of the potential health problems of a particular individual who uses such an information and recommendations to take preventive actions.

Surprisingly, rarely the analysis of microbial sensitivity/ resistance is required by the general practitioners and the specialists prior to prescribing the antibiotics in order to know in advance (to predict) what antibiotic will have an effect. In general, the broad-spectrum antibiotics are used by general practitioners to treat the patient, which consequently leads to increased antibiotic resistance. The antibiotic resistance is monitored by an excellent electronic system, run by the Public Health Authority of the Slovak Republic and called SNARS (Slovak National Antimicrobial Resistance Surveillance System) [12]. Since the year 2000 , the system collects the data from the clinical microbiology laboratories and offers statistical analysis of microbial resistance and the probable agents of infectious diseases in the particular regions of the Slovak Republic. Using this system, any general practitioner or specialist can predict, with the particular degree of probability, the most probable infectious agent(s) and start targeted therapy while requesting the analysis of the biological material to confirm the expectations. The important and useful data on the epidemiological situation in the Slovak Republic is available through EPIS (Epidemiological Information System) [13]. Knowing the epidemiological situation, healthcare professionals can predict potential problems in the particular regions and suggest respective preventive actions. In general, the role of information systems in healthcare [14, 15] has been recognized as important for future progress and the project of implementing e-health in the Slovak Republic has started in 2009 [7]. The coordinating role in the project of implementation e-health is covered by the National Health Information Center [16], the state contributory organization, established in February 2006 by the Ministry of Health of the Slovak Republic. The main components of the e-health implementation include the National Health Portal, National Health Information System, Health Information Network and the National Health Data Center [17]. As soon as the entire project of e-health is implemented, it will, undoubtedly, offer very powerful tool and support for the predictive, preventive and personalized medicine in the Slovak Republic. On the other hand, however, substantially more attention must be paid to the ethical issues and to the new legislation related to this project in order to respect the rights of the citizens, if the entire project is not to be misdirect against the citizens instead of bringing the benefits and the improvements in the healthcare $[14,15]$.

\section{Current health-related preventive programs in the Slovak Republic}

The key document in prevention is the Act No. 576/2004 Coll., as amended and supplemented by later regulations and the National Health Promotion Program (NHPP) [9] updated in July, 2005, with the primary objective of initiating the partnership of the particular components of the society to provide support and continual improvement of the public health. The eleven objectives of the program are the following: healthy lifestyle, healthcare, healthy nutrition, reduction of the damages due to alcohol, drugs and tobacco products, prevention of injuries, healthy family, healthy working conditions, healthy living conditions, reduction of the incidence of the infectious diseases, reduction of the incidence of the non-infectious diseases, and physical activity. Each objective is consequently specified in the program. It is very important that the search for pathological processes in their asymptomatic stages and the consequent treatment preventing the clinical manifestation is emphasized in the program, which is in agreement with the objectives of predictive, preventive and personalized medicine, and so is the role of the healthy nutrition and physical activity. The entire NHPP in the Slovak Republic may serve as a very good base for the implementation of PPPM in the Slovak healthcare system and the everyday life of the people.

Among other preventive programs we find: Centers of Maternal Care Program, Children and Adolescents Care National Program, Schools-Supporting-Health Program, Program of Health Promotion in Preschool Children, Obesity Prevention National Program, Circulatory Diseases Prevention Program, Cancer Prevention Program, National Program on Mental Health, CINDI Screening Program, School Fruit Scheme and other preventive programs, which are summarized at the web page of the Public Health Authority of the Slovak Republic [11, 18].

The disease prevention is mainly focused on improving the public health and the public-health-related statistics. From the PPPM point of view, however, we have to pay attention primarily at the health of an individual citizen, keeping it at the spotlight of the healthcare. Consequently, we can expect that the overall population statistics will improve. Public health is a virtual statistical category arising from the health of the individual citizens, while a health of any particular citizen is a fact that does not arise from any public health statistics. The "individual" and "public" health attitudes complement each other, but the 
role of the "personalized" aspect of prevention must be more emphasized in the healthcare of the Slovak Republic.

According to the authors of this overview, the best level of the individual prevention in the Slovak Republic is established in the field of gynecology, the prenatal care and the children care.

Substantially less attention in the daily healthcare is paid to the role of the nutrition and the potentially harmful compounds found in the food, despite the fact that nutrition is an important objective in the NHPP.

\section{Personalized medicine in the Slovak Republic}

At this point, again, it is very important to emphasize the simple fact: it is highly improbable that an individual suffering of, for example, headache feels better if informed that $99.99 \%$ of the population suffers not at a time. We have to realize that a patient does not care about the population statistics, the patient cares about the health of him- or herself and the health of the close relatives. Hardly can we expect a mother, whose child died of a particular medical procedure, to be happy after being informed that this procedure, otherwise, works well in, say, 99.9999\% of the cases. The contrary is true, and the mother rightfully asks why was the current medicine incapable of predicting health complications in her child before the procedure was even suggested? This is the "personalized" aspect of the most advanced medical and life sciences and the latest health-related technology. Such a level of medicine is not achieved in the Slovak Republic, although some exceptions may be found in the personalized pharmacogenomics, where a patient is tested for the particular mutation prior to prescribing a therapy which may be inefficient, or even harmful, if the mutation is present. Another example of personalized attitude is the prescription of the drug with respect to patient's individual metabolism and possible interactions with other drugs, as well as the special treatment of immunocompromised patients with transplant organs. The field of prosthetics is inevitably personalized.

The "personalized" aspect of predictive, preventive and personalized medicine in the Slovak Republic is just at the beginning. We expect, however, that the situation will gradually improve with the implementation of PPPM in the healthcare system and the new legislation will take into consideration this scientific and technological progress.

\section{Healthcare education in the Slovak Republic and the ethical dilemmas in the context of PPPM}

Health-related education plays an essential role in the PPPM. In this respect, the situation in the Slovak Republic is far from optimum. Regardless the objectives stated in the NHPP, substantially less attention is paid to education regarding the role of nutrition and other factors in sustaining health over the life time.

The education activities related to health in the Slovak Republic may be simply summarized as follows:

1. Parental and Pre-school education: "Wash your hands before eating anything", "Wash the fruits and vegetables", "Wash your hands after using toilet", "Brush your teeth", "Don't sit on the cold ground", "Take a warm clothes", "Don't eat to much chocolate" and other similar parental education activities towards their children;

2. Elementary school education: Irregular lectures on dental hygiene and some of the first aid instructions at the biology classes;

3. Secondary school (except medical schools): No special education as for the healthcare except certain irregular lectures on sexually transmitted diseases and the ways of protection, the lectures on the theme "Alcohol, tobacco and drugs are seriously dangerous" seem to be too late at this level;

4. University (except faculties of medicine): No special education as for the healthcare;

5. Post gradual education (faculties of medicine): special courses focused on the new trends, the role of nutrition and nutritional components in sustaining health;

6. Self education: web-based information dedicated to the health are relatively frequent (see Table 4) but no Slovak web is registered at the Health on the Net Foundation [19] as a source of the reliable healthrelated information. The books on herbs, diets, food, alternative medicine, natural products, nutrition supplements, vitamins, and other books, together with the personal experience as well as advices and recommendations from close relatives and friends, are among the most frequent sources of knowledge for health-related education.

It is clear from this simple list, that the most information related to the healthcare we receive from our parents early at the childhood and the next information comes at the adulthood as soon as we start to feel bad and seek the information available. Health-related education is missing in the Slovak Republic. The most appropriate level for introducing health-related education is the elementary school.

Sadly enough it seems that individual health is not so important even for the individual person - contrary to what is always being declared by the people. On one hand, people in Slovakia, and probably elsewhere, use to say that the health is the most valuable for them, on the other, they say, sarcastically, they don't want to die healthy, and, as a matter of sad fact, they are very successful in fulfilling this goal, since $95 \%$ of the Slovak population really die of some 
diseases. The good health at the higher age is a rare phenomenon in the Slovak Republic. The lifestyle of the Slovak population can hardly be regarded to as healthy. Despite of all the effort and the education campaigns, $41 \%$ of the population smoke regularly or occasionally, and the consumption of the alcoholic drinks was 106.31 per inhabitant in the year 2008 [20]. Partly it is due to the social and economical aspects, and in the other part it is the influence of the modern civilization which is gradually and globally lacking the potential of offering the meaningful philosophy for the lifetime, other than the one like "Buy our product at the lowest price to save the money for buying another product of ours" and, of course, another one like "Work as long as you can and then die - preferably prior to your retirement".

In general, the lifetime philosophy and the perspectives for the future progress of the entire civilization is the serious issue in the context of the predictive, preventive and personalized medicine, and poses uncomfortable ethical dilemmas which must be solved. The role of education in this process is irreplaceable and must be recognized by the whole society.

As true for the vast majority of the countries in the world, if not to say all, the current system of healthcare in the Slovak Republic is better to be referred to as the "diseasecare" rather than a real healthcare, where the health is in the spotlight since the childhood. The financial resources are commonly wasted on the therapy of preventable diseases and the potential of new technological and scientific progress is very often misdirected.

\section{Conclusion and recommendations}

All components of the healthcare system in the Slovak Republic, as outlined in the Figs. 2 and 3 are very important for the proper function of the system. Although many people may complain, the healthcare system in the Slovak Republic is not as bad as it seems at the first glance, or if judging by the personal and "hands-on" experience. It, however, needs improvements, specific changes and implementation of the new ideas, trends and technology. The healthcare system in the Slovak Republic has the potential of being substantially better if wisely governed in the years to come. The new government has all the tools at its hands. The always-pronounced lack of the financial resources should not be the reason for keeping the system at current stagnant state. On the contrary, it should stimulate wise re-distribution of the financial resources and the investment into the new perspective trend of predictive, preventive and personalized medicine, which has clear potential of saving money in the future, while stimulating economical growth at the same time for a simple reason-the healthier population will bring more money through value added tax and will be able and willing to work even at higher age.
We believe that the following recommendations for the improvements of the healthcare system in the Slovak Republic may be of relevance for the new government and may be found inspiring also for other countries:

1. update the National Health Promotion Program with PPPM and do follow it;

2. more emphasis should be put on the modern laboratory diagnostics and in vivo diagnostics and their predictive potential;

3. enhance technology transfer from the medical research into the daily healthcare;

4. implement PPPM education programs at the appropriate levels of education system in the Slovak Republic;

5. reconsider the scope and the related ethical issues and implement e-health and the health-related web portals with the reliable information for the public and the medical professionals;

6. support implementation of the recent information technology at all levels of healthcare system;

7. update the respective legislation and create a new one to protect the rights of the citizens/patients;

8. co-ordinate the roles played by all components of the healthcare system;

9. emphasize the role of the healthy nutrition and implement the technology for fast, affordable and convenient analysis of the individual food;

10. motivate people who do take care of their own health;

11. essentially pay attention to the ethical issues, related to PPPM;

12. respect rights of the individual patient;

13. stress the personalized aspect of the healthcare, treat the individual patient not the statistical entity called "public health";

14. allocate financial resources now and they will return in the lower healthcare spending in the future;

15. decrease the consumption of medical drugs;

16. regularly evaluate the impact on the healthcare economy and monitor emerging trends;

17. support and monitor the evidence-based quality of the healthcare services;

18. set new standards for quality in healthcare at all levels prepare the profile of the desired healthcare provider in the particular service (GP, Specialist, Clinical Laboratory, Hospital, Health Insurance, Pharmacy, Emergency medical service, other related services such as education, medical research).

\section{References}

1. http://jaspi.justice.gov.sk/jaspiw1/jaspiw_mini_fro.htm. Accessed 17 Oct 2010 
2. https://lt.justice.gov.sk/Default.aspx. Accessed 17 Oct 2010

3. http://www.zbierka.sk. Accessed 17 Oct 2010

4. http://www.rokovania.sk/Rokovanie.aspx/BodRokovaniaDetail? idMaterial $=8893$. Accessed 17 Oct 2010

5. https://lt.justice.gov.sk/Document/DocumentDetails.aspx? instEID $=-1 \&$ matEID $=1740 \&$ docEID $=69887 \&$ docFormEID $=-$ $1 \&$ docTypeEID $=1 \&$ langEID $=1$. Accessed 17 Oct 2010

6. http://www.nczisk.sk/buxus/generate_page.php?page_id=565. Accessed 17 Oct 2010

7. http://www.ezdravotnictvo.sk/. Accessed 17 Oct 2010

8. http://portal.statistics.sk/files/Sekcie/sek_600/Demografia/Obyva telstvo/2010/preddef_tab_09_aj.pdf. Accessed 17 Oct 2010

9. http://www.uvzsr.sk/docs/info/podpora/narodny program en.pdf, National Health Promotion Program, 2005: 1-20. Accessed 17 Oct 2010

10. http://www.nczisk.sk/buxus/generate_page.php?page_id=483. Accessed 17 Oct 2010

11. http://www.uvzsr.sk. Accessed 17 Oct 2010

12. http://www.snars.sk. Accessed 17 Oct 2010
13. http://www.epis.sk. Accessed 17 Oct 2010

14. Kapalla M, Kapallová D (2009) Information systems as an essential component of prediction in laboratory diagnostics In: Golubnitschaja $\mathrm{O}$, editor. Predictive diagnostics and personalized treatment: dream or reality. New York: Nova Science Publishers, pp. 529-548 668

15. Kapalla M. Healthcare information complexity and the role of informatics in predictive, preventive and personalized medicine. In: Niederlag W, Lemke HU, Rienhoff O, editors. Personalisierte medizin und informationstechnologie. Band 15. Dresden: Health Academy; 2010. p. 83-108.

16. http://www.nczisk.sk. Accessed 17 Oct 2010

17. http://www.nczisk.sk/buxus/generate_page.php?page_id=565. Accessed 17 Oct 2010

18. http://www.uvzsr.sk/index.php?option=com_content\&view= category\&layout $=$ blog\&id $=69 \&$ Itemid $=74$. Accessed 17 Oct 2010

19. http://services.hon.ch/cgi-bin/HONcode/browse.pl. Accessed 17 Oct 2010

20. http://portal.statistics.sk/showdoc.do?docid=20448. Accessed 17 Oct 2010 